УДК 615.32

DOI: $10.18101 / 2306-1995-2020-1-3-8$

\title{
ЛЕКАРСТВЕННЫЕ СРЕДСТВА НА ОСНОВЕ РАСТИТЕЛЬНЫХ РЕСУРСОВ БАЙКАЛЬСКОГО РЕГИОНА
}

\section{(C) Николаев Сергей Матвеевич}

доктор медицинских наук, профессор, главный научный сотрудник,

Институт общей и экспериментальной биологии СО РАН

Россия, 670047, г. Улан-Удэ, ул. Сахьяновой, 6 smnikolaev@mail.ru

\section{(C) Чукаев Сергей Александрович}

кандидат медицинских наук, доцент, доцент кафедры фармакологии, клинической фармакологии с курсом биохимии медицинского института Бурятский государственный университет имени Доржи Банзарова Россия, 670002, г. Улан-Удэ, ул. Октябрьская, 36а s-chukaev@mail.ru

Аннотация. В данной работе приведены исторические и современные данные по исследованиям лекарственных растений Байкальского региона, а также использованию их в составе комплексных лекарственных препаратов традиционной медицины. Задачей настоящей работы явилось рассмотрение исторических и современных аспектов изучения лекарственных растений региона, разработки на их основе лекарственных и оздоровительных средств в современных готовых формах. В статье подчеркивается роль сотрудников Иркутского государственного университета в изучении Байкальской флоры, используемой в традиционной медицине, а также других организаций. Особо выделен вклад сотрудников Бурятского научного центра Сибирского отделения Российской академии наук и медицинского института Бурятского государственного университета имени Доржи Банзарова Минобрнауки РФ в создание новых лекарственных и оздоровительных средств на базе растительных ресурсов Байкальского региона.

Ключевые слова: Байкальский регион; Иркутский государственный университет; Бурятский государственный университет; Бурятский научный центр; лекарственные и оздоровительные средства. 


\section{Для цитирования}

Николаев С. М., Чукаев С. А. Лекарственные средства на основе растительных ресурсов Байкальского региона // Вестник Бурятского государственного университета. Медицина и формация. 2020. Вып. 1. С. 3-8.

В Байкальском регионе повышению интереса медицинского сообщества и населения к использованию лекарственных растений и лекарственных препаратов из них способствовала успешная практика эмчи-лам при лечении и профилактики заболеваний [1-3]. Об этом впервые О. О. Реман, будучи врачом Посольства России в Китае, описал практику использования лекарственных растений в регионе и издал работу на немецком языке в Санкт-Петербурге под названием «Описание тибе тской аптечки» (1811 г). Затем, Архиепископ Ирку тска Нил (Н. Ф. Исаакович), ознакомившись с практикой эмчи-лам по использованию местных видов лекарственных растений при лечении заболеваний, издал в 1875 году книгу «Врачебное искусство забайкальских лам» [4].

Задачей настоящей работы явилось рассмотрение исторических и современных аспектов изучения лекарственных растений Байкальского региона, создания на их основе лекарственных и оздоровительных средств. Указанные работы, а также широкая практика применения лекарственных растений эмчи-ламами с целью приготовления лекарств заинтересовали ученых Иркутского государственного университета профессора Обергарда И.А., работавшего в то время в Лаборатории фармакологии медицинского факультета, а затем профессора Н. П. Шаврова, который заведовал кафедрой фармакологии и фармацевтической химии [4; 8]. В частности, профессор Н. П. Шавров со своими учениками Нестеровым А. И., Семеновым С. Р. изучал химический состав популярных лекарственных растений Байкальского региона, а также рецептурные прописи многокомпонентных препаратов, используемых местными эмчиламами. Их интересовало фармакологическое свойство извлечений из лекарственных растений, эффективность при их применении, а также безопасность использования при длительных курсах лечения больных. Сотрудник этой же кафедры Варлаков М. Н., будучи руководителем экспедиций, изучал наиболее часто используемые виды растений, а также прописи комплексных препаратов, прин имая непосредственное участие в приеме больных и назначении их эмчи-ламами при дацанах. Он, работая на кафедре в Иркутске и одновременно в Сибирском филиале Московского научно-исследовательского химико-фармацевтического института в Новосибирске, разработал и внедрил ряд, новых препаратов из 
C. М. Николаев, С. А. Чукаев. Лекарственные средства на основе растительных ресурсов Байкальского региона

растений Байкальского региона. Так, им были предложены препараты из термопсиса ланцетовидного, синюхи голубой и другие средства $[4 ; 8]$. Его интерес к лекарственным растениям региона, используемых эмчиламами, опыту лечения болезней в дацанах поддерживался профессором Г. Ц. Цыби ковым - востоковедом Иркутского государс твенного университета. Профессор Цыбиков Г. Ц. обеспечивал М. Н. Варлакова перев одами бурятских, монгол ьских, тибетских медиц инских письменных источников, рецептурников - чжоров. Благодаря такому сотрудничеству Варлакову М. Н. удалось составить списки лекарственных растений на русском, латинском, тибетском, монгольском языках, используемых эмчи-ламами, а та кже описать преимуще ственные виды актив ности извлечений из них [4].

\section{Материалы и методы исследований}

Созданное основателем кафедры фармакологии профессором Шавровым М. П. научное направление по комплексному исследованию лекарственныхрастений Байкальского региона получило дальнейшее развитие. Сегодня сотрудники Иркутского государственного медицинского универ ситета продолжают изучение лекарственной флоры региона совместно с Научно-исследовательскими институтами СО РАН, высшими учеб ными заведениями Миноб рнауки РФ, располо женными в рег ионе [8].

Новый импульс в исследовании лекарственных растений Байкальского региона придан сотрудникам Научно-исследовательских институтов СО РАН и Высших учебных заведений Минобрнауки РФ Республики Бурятия и Забайкальского края. С организацией Отдела биологически активных веществ в качестве самостоятельного структурного научного подразделения при Бурятском научном центре СО РАН (ныне при Институте общей и экспериментальной биологии СО РАН) стало возможным систематическое исследование лекарственной флоры Байкальского региона, разработка биотехнологий получения современных готовых форм препаратов, рекоме ндации новых лекарственных и оздоров ительных средств с внедр ением их в клини ческую и профилактическую медицину. Сотрудниками указанного подразделения впервые разработаны и предложены методические подходы к идентификации используемого в традиционной медицине лекарственного растительного сырья и препаратов, создана база данных о лекарственных растениях региона, раскрыты общие закономерности составления прописей многокомпонентных препаратов, иссле дуются правомерности замены отдельных растений сибирскими видами в комплексных традиционных лекарствах [5; 6]. На базе лекарственной флоры Байкальского региона созданы и внедрены лекарственные препараты: полифитохолза № 001301/02-2002 в РФ, генцихол (Монголия), гентин (Грузия), из алоэ древовидного 4 готовые формы - гранулы, линимент, экстракт, пла- 
стырь (Грузия), кардекаим (Минобороны СССР); предложены для внедрения нефрофит (таблетки), тетрафит (гранулы), розобтин (гранулы) и другие препараты [7; 9]. Из лекарственных растений Байкальского региона разработаны и внедрены 15 наименований оздоровительных средств в фо рме биологически акти вных добавок к пище (БАДы), чай ных напитков, которые рекомендованы в каче стве вспомогательных, профилактических средств на территории Таможенного Союза (Россия, Беларусь, Казахстан).

Значительный вклад в изучение лекарственных растений Байкальского региона вносят сотрудники Байкальского института природопользования СО РАН, Восточно-Сибирского государственного университета технологий и управления Минобрнауки РФ. Бурятской сельскохозяйственной академии им. В. Р. Филиппова Минсельхоза РФ и другие учреждения.

\section{Заключение}

В наст оящее время усилия научных и образов ательных организаций, занима ющихся исследованием лекарс твенных растений рег иона направлены на внедрение результатов нау чных изысканий в прак тику здравоохранения и фармацев тической отрасли, подго товку предложений по совершен ствованию нормативно-правовых ак тов по исполь зованию доказанных по эффект ивности и безопа сности растительных лекарс твенных средств. В частн ости, подготовлены и напра влены в Государ ственную Думу и Минист ерство здравоохранения РФ предл ожения по допол нению федерального закона за № 61-Ф3 «Об обра щении лекарственных сред ств» по пун ктам - о необхо димости выделения фарма копеи лекарственных препа ратов растительного происх ождения как самостоя тельного раздела в общей фармакопее, ускор енной регистрации фитопрепаратов по оп ыту ряда заруб ежных стран, введению в Государ ственный реестр лекарс твенных растений Байкал ьского региона и другие данные [6]. Эти предл ожения поддержаны на заседании круглого стола в Комитете по охране здоровья Госдумы РФ. Шир окое применение вывер енных средств растительного происхождения в профилактике и лечении заболеваний ${ }^{1}$, наряду с бази сными химиопрепаратами, определенно, будет способс твовать повышению эффект ивности лечебно-профилактических мероп риятий и позв олит обеспечить снижение заболеваемости населения, повышение качества и продолжи тельности здоровой жи зни общества.

\footnotetext{
${ }^{1}$ WHO. Traditional Medicine Strategy. 2014-2023. HongKong, 2013. 75 p.
} 
C. М. Николаев, С. А. Чукаев. Лекарственные средства на основе растительных ресурсов Байкальского региона

\section{Литература}

1. Асеева Т. А., Блинова К. Ф., Яковлев Г. П. Лекарственные растения тибетской медицины. Новосибирск, 1985. 154 с.

2. Аюшиева Л. В. Роль тибетского врачевания в отечественной медицине (VII-XX вв): автореф. дис. ... канд. мед. наук, М., 2007. 24 с.

3. Баторова С. М. Растения тибетской медицины: опыт фармакогностического исследования. Новосибирск, 1989. 159 с.

4. Левента А. И. К истории изучения тибетской медицины // Сиби рский медицинский журнал. 2008. № 1. С. 103-106.

5. Николаев С. М. Фитофармакотерапия и фитофармакопрофилактика заболеваний. Улан-Удэ, 2012. 286 с.

6. Перспективы формирования интегративной системы здравоохранения / С. М. Николаев [и др.] // Комплементарная медицина: состояние и перспективы правового регулирования. М., 2015. С. 23-26.

7. Лекарственные средства на основе растительных ресурсов Байкальского региона / Е. В. Петров [и др.]. Новосибирск, 2008. 94 с.

8. Усов Л. А. К истории кафедры фармакологии Иркутского государс твенного медицинского университета // Сибирский медицинский журнал. 2007. № 6. С. 96-97.

9. Nikolaev S. M., Chukaev S. A. Traditional medicine of Buryatia: the current state and prospects for the development // Traditional medicine: ways of consolidation with modern he care. Ulan-Ude, 2019. P. 5-6. 


\section{MEDICINAL REMEDIES ON THE BASE OF PLANT RESOURCES \\ IN THE BAIKAL REGION}

Nikolaev S. Matveevich

Dr. Sci. (Medicine), professor,

Chief Researcher,

Institute of General and Experimental Biology SB RAS

6, Sakhynova str., 670047 Ulan-Ude, Russia

smnikolaev@mail.ru

\section{Chukaev S. Aleksandrovich}

Cand. Sci. (Medicine), Associate professor,

Docent of the Department of Pharmacology,

Clinical pharmacology with course of Biochemistry

Medical Institute of Dorji Banzarov̉s Buryat State University

36a, Oktyabrskaya str., 670002 Ulan-Ude, Russia

chukaev@mail.ru

Abstract. The given work reviews the historical and up-to-date data on the studies of medicinal plants in the Baikal region and their use in the composition of complex medicinal preparations of the traditional medicine. The aim of the present work was to discuss historical and modern aspects of the study of medicinal plants in the region and development of medicinal and health improving remedies on their base in the finished pharmaceutical forms.

The article emphasizes the role of the researchers from the Irkutsk State University and other institutions in the study of Baikal flora used in the traditional medicine. The article gives considerable prominence to the original contribution of the researchers from the Buryat Scientific Center of the RAS Siberian Branch and the Medical Institute of Dorji Banzarovis Buryat State University in the development of new medicinal and health improving remedies on the base of the Baikal region plant resources.

Keywords: Baikal region; Irkutsk State University; Buryat State University; Buryat Scientific Center; medicinal and health improving remedies. 